\title{
Ecological Status of Juglans cinerea in New Brunswick
}

\author{
Martin Williams, ${ }^{1, \dagger}$ Eric R. D. Moise, ${ }^{2}$ Kathleen Forbes, ${ }^{1}$ Charlene Williams, ${ }^{3}$ Ian DeMerchant, ${ }^{1}$ and Tannis Beardmore ${ }^{1}$ \\ ${ }^{1}$ Natural Resources Canada, Canadian Forest Service, Atlantic Forestry Centre, Fredericton, New Brunswick E3B 5P7, Canada \\ ${ }^{2}$ Natural Resources Canada, Canadian Forest Service, Atlantic Forestry Centre, Corner Brook, Newfoundland and Labrador A2H \\ 5G4, Canada \\ ${ }^{3}$ Vineland Research and Innovation Centre, Vineland Station, Ontario, LOR 2E0, Canada
}

\begin{abstract}
Butternut (Juglans cinerea L.), an early successional riparian hardwood species native to Canada and the United States, is under serious threat from a nonnative fungal pathogen, Ophiognomonia clavigignenti-juglandacearum. Since it was first reported in Canada in 1990, this fungal pathogen has spread rapidly and established in New Brunswick in 1997. Apart from the first report in 1997 and another in 2004, no surveys have been conducted to assess the spread of the pathogen in the province. The purpose of this research was to survey butternut throughout its range in New Brunswick, evaluate disease oc-

in New Brunswick. The disease likely only recently (2007) spread to the northeastern-most populations, given that lower rates of canker occurrence and higher health ratings are found further away from the point of initial occurrence of the disease. Although canker incidence is high throughout the province, tree dieback is minimal, and trees still producing nuts could support opportunities for ex situ conservation. Because of the rate of pathogen spread in the province, implementing a tree improvement strategy might be the only means for maintaining the butternut genome on the landscape.
\end{abstract} currence as well as tree health, and investigate the impact of different topographic and tree health factors on canker incidence. Results showed that the disease has spread throughout the range of butternut
Keywords: butternut canker, conservation, endangered, invasive forest disease, pathogen spread, survey
Butternut (Juglans cinerea L.) is native to the central and eastern United States and southeastern Canada, where the northern range edge spans three provinces: Ontario, Quebec, and New Brunswick (Committee on the Status of Endangered Wildlife in Canada 2017). In Ontario and Quebec, the species' range is restricted to a continuous stretch of land in the southern part of each province (longitude approximately $83.0364^{\circ}$ to $71.2080^{\circ} \mathrm{W}$ ). The New Brunswick range extends throughout the southwestern area of the province and is geographically isolated from the rest of the species' range in Canada and the United States; it is approximately $250 \mathrm{~km}$ from the most northern Maine populations and $200 \mathrm{~km}$ from the closest Quebec populations (Committee on the Status of Endangered Wildlife in Canada 2017). Although butternut's natural range in Maine is predominantly identified as being in the southern portion of the state (Committee on the Status of Endangered Wildlife in Canada 2017), the presence of butternut in other Maine counties has been noted (Maine Forest Service 1994, 1995, 2007). Isolated trees have been identified in Aroostook County, Maine, approximately $20 \mathrm{~km}$ from New Brunswick native stands of butternut (M. Williams, personal observation).

Butternut is under serious threat from a nonnative fungal pathogen, Ophiognomonia clavigignenti-juglandacearum (V.M.G. Nair,

${ }^{\dagger}$ Corresponding author: M. Williams; Martin.Williams@ canada.ca

Funding: This work was funded by the Interdepartmental Species at Risk Fund, Environment and Climate Change Canada, and the Canadian Forest Service.

*The $\boldsymbol{e}$-Xtra logo stands for "electronic extra" and indicates that one supplementary table is published online.

The author(s) declare no conflict of interest.

Accepted for publication 13 September 2019

The author(s) of the Work is/are employed by the Canadian Federal Government and the Work was produced during the course of his/her/their employment, and by reason of this fact, the copyright in the Work is retained by Her Majesty the Queen in Right of Canada, as represented by the Minister of Natural Resources Canada.
Kostichka \& J.E. Kuntz) (Oc-j; Broders and Boland 2011). Oc-j was first identified as a butternut pathogen in 1967 in Wisconsin (Renlund 1971). It was initially identified as Sirococcus clavigignentijuglandacearum in 1979 (Nair et al. 1979) and reclassified into the genus Ophiognomonia in 2011 (Broders and Boland 2011). This pathogen affects all tree sizes and age classes on all sites, and infection can occur through buds, leaf scars, and various wounds (Nair et al. 1979). After infection, fungal growth lifts and splits the bark, leaving sunken black marks and blemishes or cankers that coalesce around the trunk of the tree, eventually girdling the tree and causing death. The spread of plant pathogens, such as $O c-j$, is governed by complex interactions involving both environmental and biological factors and by unintentional human-mediated dispersal (e.g., movement of infected firewood). There is uncertainty as to how the canker has spread so rapidly throughout the host species' range. Local or short-distance dissemination of fungal spores (conidia) is possible through rain splash and by aerosols (Tisserat and Kuntz 1983) and insect vectors can carry spores that could enable short- or longdistance dispersal of the fungal pathogen (Halik and Bergdahl 2002, 2006; Katovich and Ostry 1998; Stewart et al. 2004). Small mammal seed dispersal up to distances of 40 to $60 \mathrm{~m}$ has been noted (Goheen and Swihart 2003; Moore et al. 2007), and the pathogen has been found on many plant tissues, including bark, leaves, and the fleshy husk surrounding the nut as well as inside the nut (Broders and Boland 2010; Innes and Rainville 1996; Tanguay et al. 2018). Hydrochory (i.e., dispersal by water) is also a potential mechanism for the spread of $O c-j$. Moore and Ostry (2015) determined that the viability of conidia, as measured by spore germination on water agar, ranged between 10 and $40 \%$ after 28 days of storage in water. Moreover, viability in water was negatively related to temperature, and some conidia still germinated after 168 days of storage in water (Moore and Ostry 2015). Conidia longevity in water could enable long-distance dispersal of $O c-j$ through watersheds because butternut is predominantly a riparian species, frequently exposed to flood waters in the spring. Water could also potentially act as a buffer to limit spore desiccation, UV damage, and exposure to variable temperatures, all factors impacting spore viability (Golan and Pringle 2017).

Since the first report of the canker disease in the United States, surveys have noted a rapid decline of butternut. In 1995, it was estimated that $77 \%$ of the southeastern U.S. butternuts were dead (U.S 
Department of Agriculture Forest Service 1995). In 2009, a northeastern U.S. survey showed a canker incidence rate of nearly $100 \%$, and mortality rates averaged $25 \%$ across the seven states surveyed (Bergdahl and Bergdahl 2009). Morin et al. (2018) reported an average loss of $58 \%$ of trees and $44 \%$ of butternut volume across 21 eastern U.S. states since the 1980s. In Canada, the first report of canker was in Quebec in 1990 (Innes and Rainville 1996), then in Ontario in 1991 (Davis et al. 1992). In 1997, the canker was identified in New Brunswick (Harrison et al. 1998), and in 2005, butternut was listed under the Canadian federal Species at Risk Act as endangered owing primarily to the impact of the canker disease. The disease was first identified in New Brunswick at five sites in Carleton County (northwestern New Brunswick) based on the characteristic signs of bleeding black cankers on stems and exposed tree roots (Harrison et al. 1998). Evidence indicated that the disease had been present at one of the sites for at least 7 years (Harrison et al. 1998), indicating a possible introduction of the disease in New Brunswick as early as 1990. In 2001, a Canadian hardwood survey identified the presence of canker disease throughout the species range in Quebec and Ontario and in Carleton County, New Brunswick (Hopkin et al. 2001). Further New Brunswick surveying in 2004 resulted in the canker being identified in four new sites within Carleton County and in two more sites in the northernmost part of the species' range in New Brunswick, in Victoria County (Aroostook, north of Bairdsville; Harrison et al. 2005). Across the U.S. border in Maine, the canker was first reported in 1993 across four southern counties (Kennebec, Lincoln, Sagadahoc, and Waldo; Maine Forest Service 1994) and across every other Maine county except Aroostook, Hancock, Penobscot, and Washington in 1994 (Maine Forest Service 1995). Further surveying in 2006 found that the disease was present in all Maine counties except for northeastern Washington County, which shares a border with southern New Brunswick (Maine Forest Service 2007).

New Brunswick is considered the last region of the species' range in North America to be impacted by the disease (Nielsen et al. 2003). Broders et al. (2012) noted that there were likely at least three separate introductions or emergences of $O c-j$ into North America, possibly through the upper Midwest via the Great Lakes and St. Lawrence Seaway, suggesting that the pathogens may have moved into New Brunswick from Quebec and/or Maine. However, the movement of the pathogen north through Maine into New Brunswick is a likely means of introduction, given the relative proximity of Maine's cankered trees to existing New Brunswick butternut compared with the next closest source of trees approximately $200 \mathrm{~km}$ away in Quebec (Committee on the Status of Endangered Wildlife in Canada 2017). Introduction from a closely related species such as Japanese walnut (Juglans ailantifolia Carrière) or through a host jump from an endophyte or a minor pathogen from North America cannot be discounted (Broders et al. 2012).

Surveying for disease spread is a valuable but time-consuming process that is not always possible because of the extent of the species' range and a lack of financial or human resources. For species at risk, assessing status is key to developing appropriate and effective conservation strategies, where it is important to have a notion of the time frame in which the species could be impacted by a given pest or pathogen. The objectives of this study were to characterize the status of butternut in New Brunswick by evaluating the following: (i) disease spread in New Brunswick since the last surveys in 1997 and 2004, (ii) the health status of New Brunswick trees, and (iii) the impact of extrinsic topographical and tree health factors on canker incidence. Results obtained from this study will be used to guide conservation strategies for the remaining butternut trees in the province.

\section{Materials and Methods}

All raw data including topographical, physical, and health attributes assessed during the surveys can be viewed in Supplementary Table S1. Because of the endangered status of the species, site GPS coordinates listed were near stands but not directly in the stand. However, actual tree coordinates were used for all distance-related calculations required in the analysis. Note that mortality was not included as part of the assessment, as the majority of land was privately owned and landowners typically removed dead or dying trees. Because butternut can hybridize with Japanese walnut and the resulting hybrids are often morphologically indistinguishable from pure butternuts, genotyping was done on all trees in the study. These results identified only three trees as hybrids. Since this information was only available after full data analysis and does not alter any of the results within this article, we did not remove these trees from the analysis.

Tree number and locations. From 2014 to 2017, 639 butternut trees from 37 naturally forested stands spanning two main Level 1 watersheds (Fig. 1; Table 1) (New Brunswick Hydrographic Network) were assessed in New Brunswick, Canada. The number of trees assessed per stand varied from 2 to 153, the majority of trees ( $n=584)$ assessed were part of the St. John River watershed, and 55 trees were located throughout the Southwest Miramichi River watershed (Table 1). Stands were initially identified using locational data from multiple sources, including the Atlantic Canada Conservation Data Centre, New Brunswick Department of Energy and Resource Development, Nature Trust New Brunswick, Fundy Model Forest, the public, and from conducting surveys of likely areas. All sites chosen were from naturally occurring stands and were within the New Brunswick native range for butternuts. However, some stands were small (e.g., two trees to over 900 trees) but were surveyed to allow for representation of butternut trees within sites that we would not have otherwise been able to capture. Surveying occurred from July to September from 2014 to 2017, to ensure full assessment of vigor and crown health parameters. For each site, the approximate number of butternut trees was estimated and, where possible, the assessed trees were evenly interspersed throughout each stand.

Topographic and tree health assessments. We evaluated and/or measured a series of topographic parameters for each tree as follows (in decimal degrees). First, location was evaluated using a Garmin Oregon 650t GPS unit. Second, elevation (in meters) of the trees' geographic location was calculated based on Furze et al. (2017) at 10-m resolution. Third, habitat type was classified as upland or riparian, where trees were identified as riparian when they had a high level of certainty of being in a floodplain (threshold $\leq 300 \mathrm{~cm}$ of water rise during flooding). This threshold value represents how high the water would have to rise for trees to be submerged at the base and is the threshold that best conforms with GeoNB's 2008 flood extent delineation for the Oromocto River (flood information application available online from GeoNB, New Brunswick government). Any value beyond that threshold is unlikely to be in a floodplain and was designated as upland. Fourth, distance (in meters) of butternut trees to a water course (e.g., stream, river, or lake) was calculated using the ArcGIS "Near" geoprocessing tool. Finally, the distance of trees to the point of initial occurrence of the 1997 Carleton County, New Brunswick site, which is the first recorded observation of the canker in the province, was calculated by measuring the distance (in meters) between the trees of interest from this 2014 to 2017 survey and the closest point of initial occurrence (coordinates from the 1997 survey; Harrison et al. 1998). Because there were five points of initial occurrence in the 1997 survey, the distance between each of the 2014 to 2017 surveyed trees and the five points of initial occurrence (Harrison et al. 1998) was calculated, and the shortest distance was used. Because of the endangered status of butternut and the increased risk of pathogen infection associated with using increment borers for age determination, core analysis to correlate diameter at breast height $(\mathrm{DBH})$ to age class was not done. DBH was measured at $1.3 \mathrm{~m}$.

Tree health assessments were conducted by evaluating tree vigor, percent live canopy, and canker incidence. Tree vigor determinations were similar to Boraks and Broders (2014), where trees were classified into one of four vigor categories as follows: vigor class 1 (V1), nearly dead (where the tree does not exhibit branch growth [no current year internodal extension of branches], and there are no leaves on terminal branches but leaves are present on epicormic shoots, and terminal branches exhibit desiccation); vigor class 2 (V2), dying (where the majority of the tree's leaves are derived from epicormic shoots, there is 
limited terminal branch growth, there is a limited number of leaves arising from terminal branches, and terminal branch desiccation is evident); vigor class 3 (V3), fairly vigorous growth (where there is evidence of terminal branch desiccation, and the tree is predominantly thriving as indicated by abundant terminal branch growth and multiple leaves on terminal branches); and vigor class 4 (V4), vigorous growth (where the tree is clearly thriving with no evidence of branch desiccation).

Percent live canopy was determined as a rating of percent live canopy (fully expanded green leaves) where trees were classified as (i) severe dieback with $<25 \%$ of the crown in leaf (\%LC1), (ii) moderate dieback with 25 to $75 \%$ of the crown in leaf (\%LC2), and (iii) minimal dieback with $>75 \%$ of the crown in leaf $(\%$ LC3). This evaluation is similar to that of Boraks and Broders (2014); however, three categories were used in this study. Canker was scored as present or absent by inspection of the roots, root collar, trunk, and upper branches.

Data analysis. The effects of elevation, distance to water, distance to initial canker occurrence, tree DBH, habitat type, and watershed on the presence of cankers were individually analyzed using logistic regression models (binomial data family, "logit" link function). The effects of canker presence and watershed on percent live canopy and vigor were analyzed using multinomial logistic regression models. Significant effects for categorical predictors and responses with more than two levels were further investigated by the Tukey honestly significant difference test to identify significantly different pairwise comparisons. All statistical analyses were conducted using the R platform (version 3.5.1, "Feather Spray"; R Core Team 2013), with the "nnet" package (version 7.3-12; Ripley 2016) to develop multinomial logistic regression models, and implementing the ANOVA function from the "car" package (version 3.0-2; Fox et al. 2012) to obtain $P$ values for the multinomial logistic regression models.

\section{Results}

Canker disease spread and health status of trees in New Brunswick. To evaluate canker disease presence and the corresponding health status of trees in New Brunswick, factors such as canker presence, tree vigor, and percent live canopy were assessed at the provincial and watershed levels. Seventy-five percent of trees were found to have cankers, and cankers were found throughout butternut's range in New Brunswick (Fig. 2; Table 1). At the watershed level, canker incidence was significantly higher $(P=0.01)$ in the St. John River watershed, where $76 \%$ of trees were cankered, compared with the Southwest Miramichi River watershed, where canker incidence was $60 \%$ (Table 1).

Across the province, 28 and $55 \%$ of the butternuts were classified as fairly vigorous and vigorous (VC3 and VC4), whereas 7 and $10 \%$ were designated as dying or nearly dead (VC1 and $\mathrm{VC} 2)$, respectively (Table 1). Watershed had a significant impact on vigor $(P=$ 0.022 ), although no within-vigor-level differences were observed despite, for example, a $20 \%$ higher probability of finding VC4 trees in the Southwest Miramichi River watershed (74\%) compared with the St. John River watershed (54\%; Fig. 3A).

Across the province, $71 \%$ of the butternuts exhibited $>75 \%$ live crowns, whereas $16 \%$ had 25 to $75 \%$ live crowns and $12 \%$ had $<25 \%$ live crowns (Table 1 ). Similarly to vigor, watershed had a significant impact on percent live canopy $(P=0.021)$. Despite a higher probability of finding $<25 \%$ live canopy trees in the St. John watershed and $>75 \%$ live canopy trees in the Southwest Miramichi River watershed, there were no significant within-category differences for any percent live canopy group (Fig. 3B).

Proximity to the point of initial occurrence had a significant effect on the probability of being cankered $(P=0.035)$, with trees closest to this point exhibiting a higher probability of being cankered than trees further away (Fig. 4A). Moreover, we observed a significant

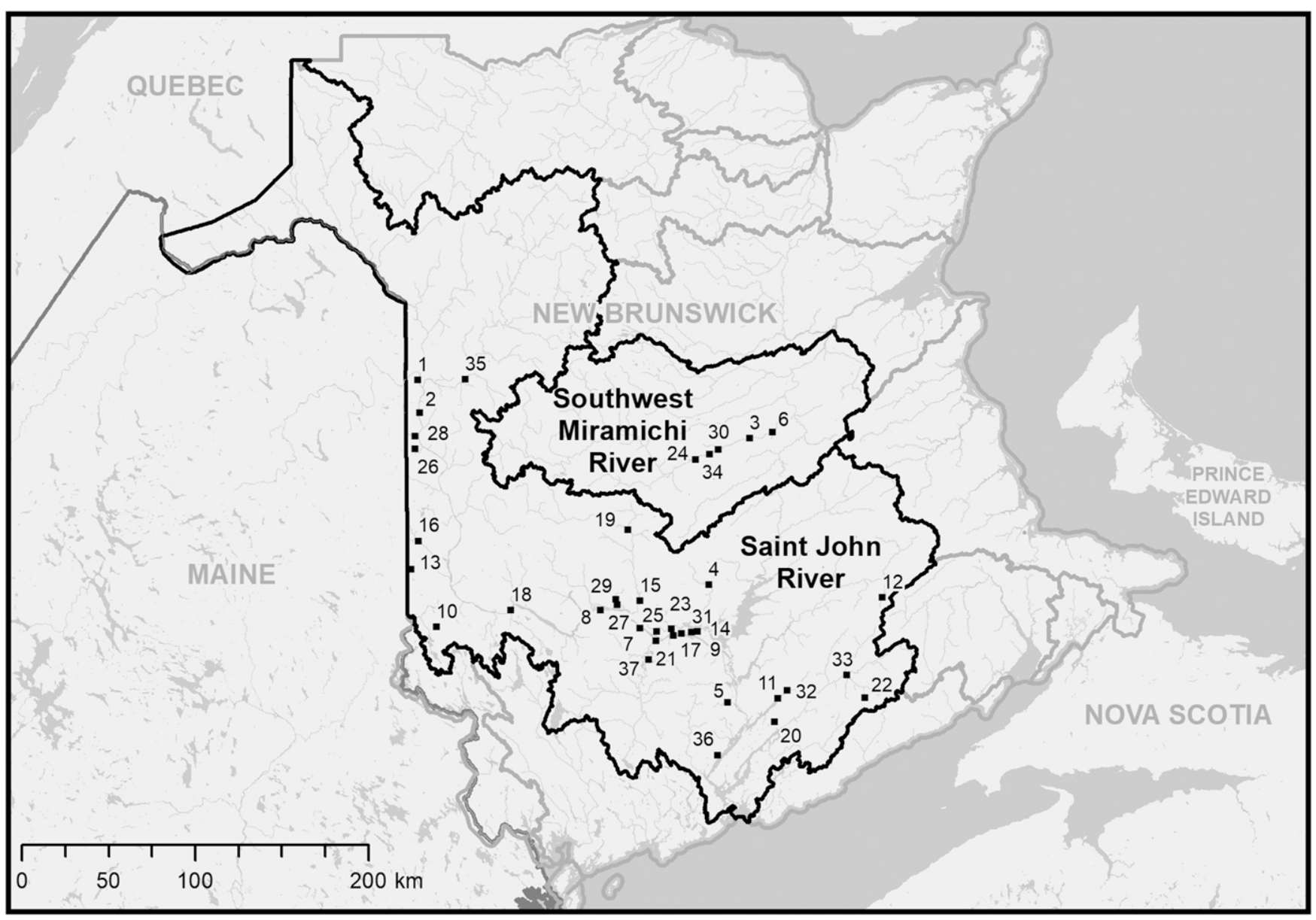

Fig. 1. Map layout of all $37 \mathrm{New}$ Brunswick butternut stands present within two of the main Level 1 watersheds in the province. 
relationship between distance to origin and both live canopy and vigor $(P<0.0001$ for both parameters; Fig. $4 \mathrm{~B}, \mathrm{C})$, such that there was a greater likelihood of finding healthier trees far from the point of initial occurrence, and trees in poorer health were more likely to be closer to the point of initial occurrence.

Topographical and health factor effects on canker incidence. Elevation of trees ranged from 2 to $256 \mathrm{~m}$, with an average elevation of $41.9 \mathrm{~m}$ and a median of $12.5 \mathrm{~m}$ (Table 2). Moreover, elevation had a significant effect on the probability of tree canker $(P=0.007)$, with cankered trees being found at elevations on average approximately $13 \mathrm{~m}$ higher than noncankered trees (45 versus $32 \mathrm{~m}$, respectively; Table 2). However, because elevation is generally higher near the Maine border as a result of the Appalachian mountain range, where canker was first found, we further analyzed the interaction between elevation and distance to the point of initial occurrence. Unsurprisingly, by including this factor, the effect of elevation was no longer significant $(P=0.067)$. Distance to water ranged from 0 to $946 \mathrm{~m}$, with an average of $155 \mathrm{~m}$ and a median of $65 \mathrm{~m}$; although cankered trees were on average closer to water than noncankered trees (average distance of trees to water: 149 and $174 \mathrm{~m}$ for cankered and noncankered trees, respectively), the relationship was not significant $(P=0.15$; Table 2). Because distance to water does not take into account floodplains (i.e., it assumes normal, nonflooding conditions), canker was evaluated according to habitat type (upland versus riparian). However, habitat type did not have a significant effect on the presence of canker $(P=0.271$; Table 2$)$. DBH was assessed to evaluate whether it could indicate canker incidence. DBH varied across New Brunswick and ranged between 1.5 and $114.8 \mathrm{~cm}$, with an average of $36.0 \mathrm{~cm}$ and a median of $34.1 \mathrm{~cm}$ (Table 2). However, DBH had no significant

Table 1. Stand and watershed data for butternut tree health attributes assessed in New Brunswick ${ }^{\mathrm{a}}$

\begin{tabular}{|c|c|c|c|c|c|c|c|c|c|c|c|}
\hline \multirow[b]{2}{*}{ Stand or watershed no. } & \multirow[b]{2}{*}{ Stand or watershed } & \multirow[b]{2}{*}{ Trees $^{\mathbf{b}}$} & \multicolumn{4}{|c|}{ Tree vigor $^{c}$} & \multicolumn{3}{|c|}{ Live canopy (\%) } & \multicolumn{2}{|c|}{$\begin{array}{c}\text { Canker } \\
\text { incidence }\end{array}$} \\
\hline & & & $\overline{\mathrm{V1}}$ & V2 & V3 & $\overline{\mathrm{V4}}$ & $<25$ & $25-75$ & $>75$ & $\overline{\text { Yes }}$ & $\overline{\text { No }}$ \\
\hline \multicolumn{12}{|l|}{ Stand } \\
\hline 1 & Aroostook & 34 & 4 & 1 & 9 & 20 & 3 & 7 & 24 & 32 & 2 \\
\hline 2 & Bishops Cemetery & 10 & 1 & 1 & 7 & 1 & 1 & 1 & 8 & 8 & 2 \\
\hline 3 & Blissfield & $9(2)$ & 0 & 0 & 2 & 5 & 0 & 1 & 6 & 9 & 0 \\
\hline 4 & Butternut Island & 4 & 2 & 0 & 0 & 2 & 2 & 0 & 2 & 2 & 2 \\
\hline 5 & Central Hampstead & $3(3)$ & 0 & 0 & 0 & 0 & 0 & 0 & 0 & 3 & 0 \\
\hline 6 & Donnely Brook & 19 & 2 & 1 & 4 & 12 & 3 & 1 & 15 & 2 & 17 \\
\hline 7 & Fredericton southeast & $13(7)$ & 0 & 0 & 2 & 4 & 0 & 0 & 6 & 10 & 3 \\
\hline 8 & Fredericton southwest & 51 & 1 & 4 & 20 & 26 & 4 & 9 & 38 & 37 & 14 \\
\hline 9 & Gilbert Island & $23(1)$ & 1 & 0 & 14 & 7 & 1 & 3 & 18 & 16 & 7 \\
\hline 10 & Hartin Settlement & 6 & 0 & 1 & 3 & 2 & 1 & 3 & 2 & 5 & 1 \\
\hline 11 & Hatfield Point & 2 & 1 & 0 & 1 & 0 & 1 & 0 & 1 & 2 & 0 \\
\hline 12 & Havelock & 20 & 6 & 5 & 3 & 6 & 8 & 3 & 9 & 19 & 1 \\
\hline 13 & Hovey Hill & 19 & 4 & 4 & 4 & 7 & 6 & 6 & 7 & 11 & 8 \\
\hline 14 & Loders Creek & 8 & 0 & 0 & 1 & 7 & 0 & 0 & 8 & 5 & 3 \\
\hline 15 & Marysville & 3 & 0 & 0 & 0 & 3 & 0 & 0 & 3 & 1 & 2 \\
\hline 16 & Meduxnekeag & 31 & 6 & 11 & 10 & 4 & 16 & 9 & 6 & 31 & 0 \\
\hline 17 & Middle Island & 2 & 0 & 0 & 1 & 1 & 0 & 1 & 1 & 1 & 1 \\
\hline 18 & Nackawic & 6 & 0 & 0 & 1 & 5 & 0 & 0 & 6 & 4 & 2 \\
\hline 19 & Nashwaak Bridge & $4(2)$ & 0 & 0 & 1 & 1 & 0 & 0 & 2 & 1 & 3 \\
\hline 20 & Norton & $4(3)$ & 0 & 0 & 0 & 1 & 0 & 0 & 1 & 4 & 0 \\
\hline 21 & Oromocto & $153(1)$ & 4 & 21 & 43 & 84 & 14 & 30 & 108 & 125 & 28 \\
\hline 22 & Parlee Brook & $2(2)$ & 0 & 0 & 0 & 0 & 0 & 0 & 0 & 2 & 0 \\
\hline 23 & Portobello & $5(5)$ & 0 & 0 & 0 & 0 & 0 & 0 & 0 & 3 & 2 \\
\hline 24 & Priceville & 3 & 0 & 0 & 0 & 3 & 0 & 0 & 3 & 2 & 1 \\
\hline 25 & Pumpkin patch & 43 & 0 & 0 & 7 & 36 & 0 & 1 & 42 & 22 & 21 \\
\hline 26 & Reid Lake & 17 & 4 & 6 & 4 & 3 & 7 & 4 & 6 & 16 & 1 \\
\hline 27 & Ring Road & 20 & 0 & 4 & 11 & 5 & 1 & 7 & 12 & 9 & 11 \\
\hline 28 & Riviere de Chute & 20 & 4 & 1 & 6 & 9 & 5 & 5 & 10 & 19 & 1 \\
\hline 29 & Royal Road & 14 & 0 & 0 & 6 & 8 & 0 & 2 & 12 & 11 & 3 \\
\hline 30 & Russel Rapids Island & 20 & 0 & 1 & 3 & 16 & 0 & 2 & 18 & 17 & 3 \\
\hline 31 & Sheffield & 21 & 0 & 1 & 2 & 18 & 1 & 0 & 20 & 11 & 10 \\
\hline 32 & Springfield & 4 & 0 & 0 & 1 & 3 & 0 & 0 & 4 & 1 & 3 \\
\hline 33 & Sussex & $19(1)$ & 0 & 0 & 4 & 14 & 0 & 3 & 15 & 16 & 3 \\
\hline 34 & Sutter lodge & 4 & 0 & 0 & 1 & 3 & 0 & 0 & 4 & 3 & 1 \\
\hline 35 & Tobique & 15 & 1 & 0 & 1 & 13 & 1 & 0 & 14 & 10 & 5 \\
\hline 36 & Victoria Beach & $3(3)$ & 0 & 0 & 0 & 0 & 0 & 0 & 0 & 3 & 0 \\
\hline 37 & Waterville & 5 & 0 & 1 & 1 & 3 & 0 & 1 & 4 & 4 & 1 \\
\hline Watershed & Watershed & & & & & & & & & & \\
\hline 1 & Southwest Miramichi River & $55(2)$ & 2 & 2 & 10 & 39 & 3 & 4 & 46 & 33 & 22 \\
\hline 2 & St. John River & $584(28)$ & 39 & 61 & 163 & 293 & 72 & 95 & 389 & 444 & 140 \\
\hline Total trees & & $639(30)$ & 41 & 63 & 173 & 332 & 75 & 99 & 435 & 477 & 162 \\
\hline
\end{tabular}

a Values are presented as the number of trees unless otherwise indicated.

${ }^{\mathrm{b}}$ Data for tree vigor and percent live canopy were not available for a total of 30 trees (values in parentheses). However, all trees $(N=639)$ were evaluated for canker.

c Vigor was classified as follows: vigor class 1 (V1), nearly dead (where the tree has no leaves except on epicormic shoots and very high desiccation levels); vigor class 2 (V2), dying (where the majority of leaves are derived from epicormic shoots, and there are high desiccation levels); vigor class 3 (V3), fairly vigorous growth (where the tree has abundant terminal branch growth and multiple leaves on terminal branches, and there is evidence of terminal branch desiccation); and vigor class 4 (V4), vigorous growth (where the tree is clearly thriving with no evidence of branch desiccation). 
effect on canker incidence ( $P=0.939$; Table 2$)$, indicating that canker infects trees of all sizes and ages.

The effects of canker on multiple tree health-related parameters, including tree vigor and percent live canopy, were assessed. Canker had a significant impact on both vigor $(P<0.001)$ and percent live canopy $(P<0.001$; Fig. 5$)$. Post hoc Tukey analysis revealed that within class, the only significant difference in canker probability was observed in $\mathrm{VC} 4$, where the probability of noncankered trees was higher than cankered trees (Fig. 5A). Similar results were found for percent live canopy, where the probability of finding a tree with a healthier canopy $(>75 \%)$ was significantly higher in noncankered trees than in cankered trees (Fig. 5B).

\section{Discussion}

Canker incidence and disease spread has increased in New Brunswick. It has taken only approximately 30 years for the butternut canker to make its way to the northeastern-most part of its range in the province of New Brunswick, Canada (Harrison et al. 1998), from the location where canker was first identified in 1967 (Renlund 1971), a distance of 2,000 km (from Wisconsin to the U.S./Canada border in Maine). Three surveys have assessed the health of New Brunswick butternut: the 1997 survey (Harrison et al. 1998), the 2004 survey (Harrison et al. 2005), and this study, conducted between 2014 and 2017. This survey further assessed the spread of canker as well as the health of the trees at the provincial and major watersheds throughout butternut's New Brunswick range. The relationships between canker and (i) different extrinsic topographical parameters and (ii) health factors were also assessed. The data from this survey provide a unique opportunity to evaluate the current state of butternut and spread of the butternut canker since the 1997 survey, which likely represents the first introduction of the disease in New Brunswick in 1990.

Based on our survey, $75 \%$ of trees are now cankered, and the disease is now found throughout the range of butternut in New Brunswick. This canker incidence rate is similar to the rate observed in the United States (Bergdahl and Bergdahl 2009; Morin et al. 2018) and in Ontario and Quebec (Committee on the Status of Endangered Wildlife in Canada 2017; Hopkin et al. 2001). Mortality was not assessed in this survey because the majority of land was privately owned and landowners typically removed dead or dying trees; therefore, the severity of the disease is likely a conservative estimate.

In considering the disease range expansion, this occurred over an estimated 28 years (1990 to 2018) during which time $O c-j$ spread $140 \mathrm{~km}$ to the northeastern-most New Brunswick stands in the Southwest Miramichi River watershed and $200 \mathrm{~km}$ into the southeasternmost New Brunswick stands (Havelock, site 12). Spread from the Maine border is supported by our survey data, which indicate that the probability of finding cankered trees is significantly higher when trees are closer to the point of initial occurrence. Health parameters also support this trend because the probability of finding healthier trees, based on tree vigor and percent live canopy, increased further from the point of initial occurrence. Interestingly, the most northeastern stand at Donnely Brook (site 6; Fig. 1) in the Southwest Miramichi River watershed had the lowest percentage of tree canker incidence in our study (11\%, two trees cankered out of 19 trees), suggesting that the canker may have been recently (after 2007; D. McPhee, personal communication) introduced there. However, stands near this site (e.g., 10 to $30 \mathrm{~km}$ ) further south in the Southwest Miramichi River watershed, such as Blissfield, Russel Rapids Islands, Sutter Lodge, and

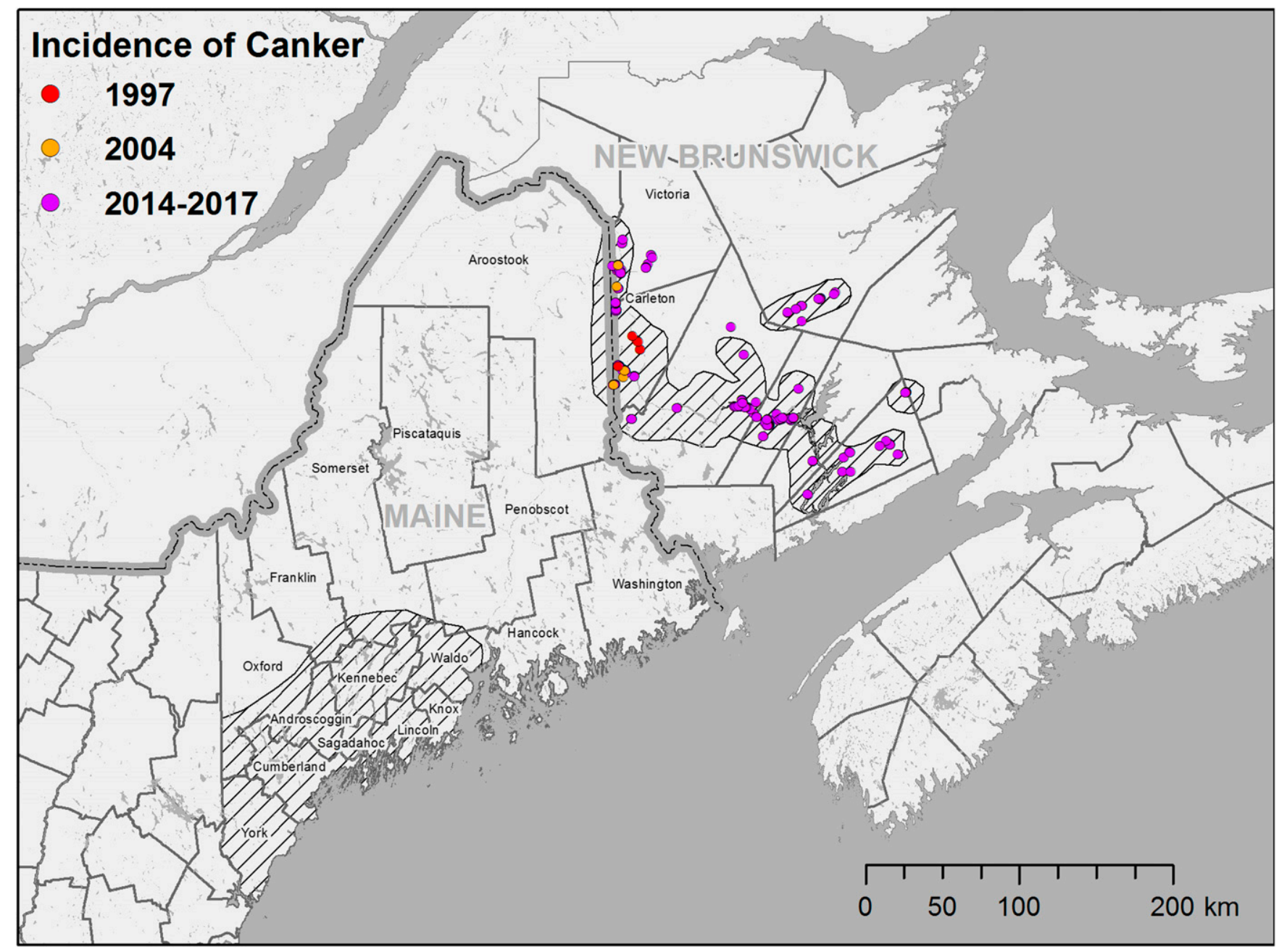

Fig. 2. Map showing butternut's natural range (lined area) in New Brunswick, Canada, and Maine, U.S.A., as well as the location of cankered trees evaluated during three separate surveys. The natural range is delineated by the lined area. 
Priceville (sites 3, 30, 34, and 24; Fig. 1), all had canker incidence rates that were comparable to the rest of the province.

Stands in the most southeastern part of the province were all highly cankered, even though the distance to the initial point of occurrence was greater $(200 \mathrm{~km})$. One explanation for a faster spread in the southeastern part of the province could involve dispersal of spores through hydrochory, where flooding and rains could have resulted in dispersal of conidia from infected trees into adjacent streams and rivers, which flow south into the Bay of Fundy. In New Brunswick, $56 \%$ of trees surveyed are from riparian sites, and spring flooding, occurring annually, can be extensive within the St. John River and Southwest Miramichi River watersheds. Since the point of initial occurrence is closer to the St. John River watershed, earlier infection of trees along the St. John River and further dispersal through hydrochory is highly likely and could explain a greater spread of the canker within the St. John River watershed compared with the Southwest Miramichi River watershed. This finding is supported by our data, where there is significantly less canker in the trees located in the Southwest Miramichi River watershed.

In considering the Southwest Miramichi River watershed, these trees were the last in New Brunswick to be infected with $O c-j$ (M. Toner, personal communication). Because these watersheds are not connected to one another, movement of $O c$-j to the Southwest Miramichi River watershed may also have been facilitated by other vectors, such as insects (Halik and Bergdahl 2002; Katovich and
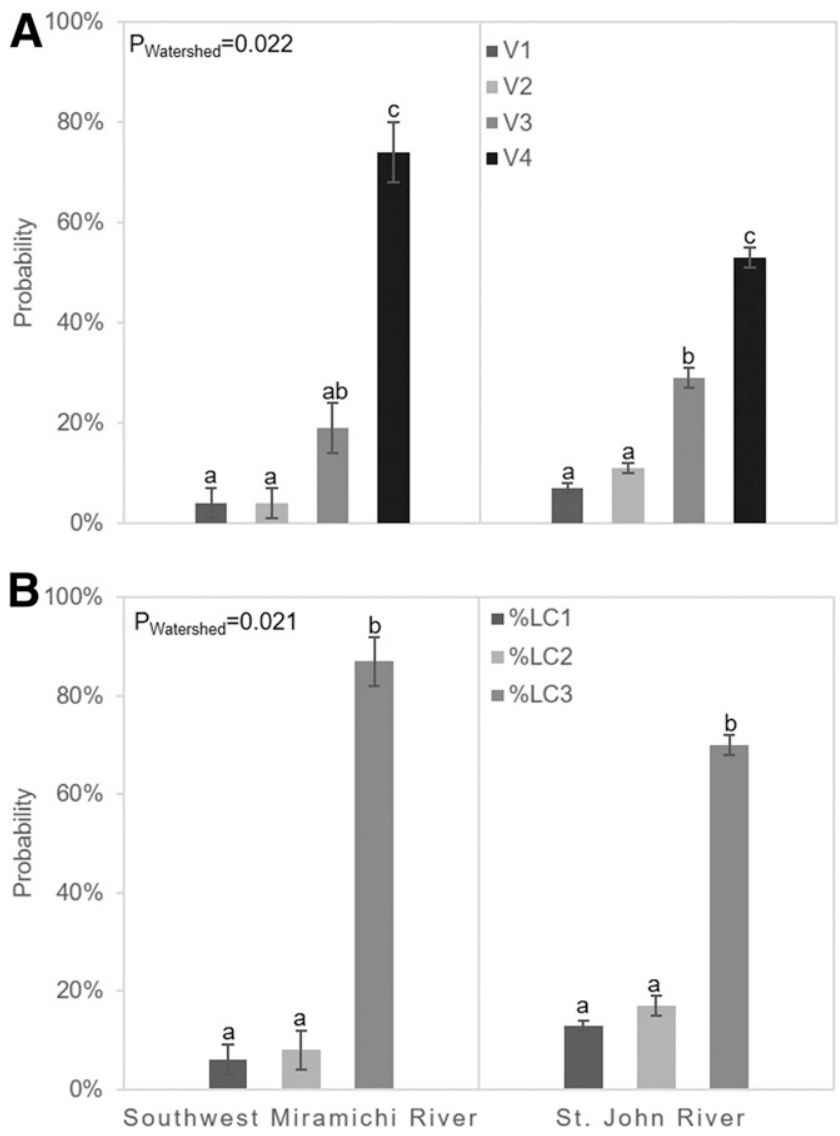

Fig. 3. Effect of watershed on the probability of A, tree vigor class and B, tree percent live canopy (\%LC). Vigor was classified as follows: vigor class 1 (V1), nearly dead (where the tree has no leaves except on epicormic shoots and very high desiccation levels); vigor class 2 (V2), dying (where the majority of leaves are derived from epicormic shoots, and there are high desiccation levels); vigor class 3 (V3), fairly vigorous growth (where the tree has abundant terminal branch growth and multiple leaves on terminal branches, and there is evidence of terminal branch desiccation); and vigor class 4 (V4), vigorous growth (where the tree is clearly thriving with no evidence of branch desiccation). Percent live canopy was defined as follows: \%LC1, <25\%; \%LC2, 25 to $75 \%$; and $\%$ LC3, $>75 \%$. Different letter combinations above standard error bars indicate significant pairwise differences in probability.
Ostry 1998), birds, or human-mediated dispersal via infected lumber or butternuts. However, environmental conditions (e.g., temperature, precipitation) in the northeastern part of the range could also have had an impact on the spread of $O c-j$. A 2018 study (Sambaraju et al. 2018) found that weather influences $O c-j$ epidemiology, where many meteorological variables including temperature, precipitation, and water deficit calculated over a 3- or 5-year cycle were all positively associated with canker severity or overall disease severity. The relationship between these climate variables and $O c-j$ is complex, as these variables can be both a benefit and a deterrent to the tree and/or pathogen. For butternut, there is little apparent genetic resistance or tolerance to $O c-j$ (LaBonte et al. 2015), and any factors benefitting optimal canker growth would tip the scale toward increased disease severity. Although these climate-related variables might increase disease severity and its spread (e.g., precipitation resulting in flooding), alternatively these variables (e.g., decreased precipitation) might limit $O c-j$ spread if pathogen viability is impacted. In New Brunswick, the distance from the point of initial $O c-j$ occurrence to the full northeastern range of butternut is short, so it is unlikely that vector availability attributable to climatic variables was the cause; however, increased distance between butternut
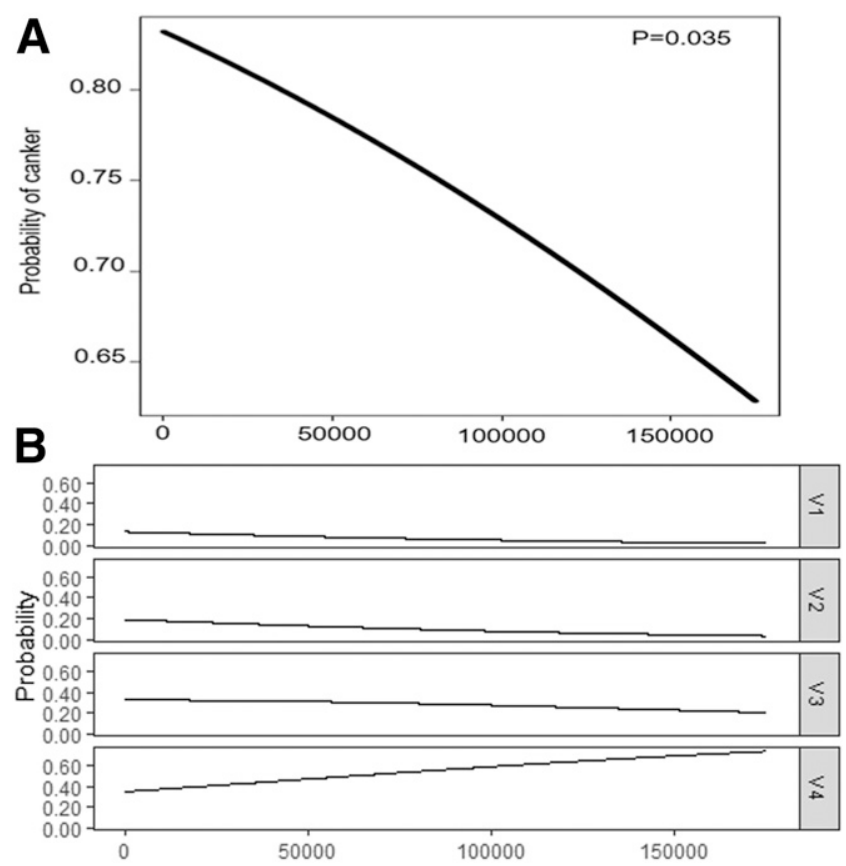

C

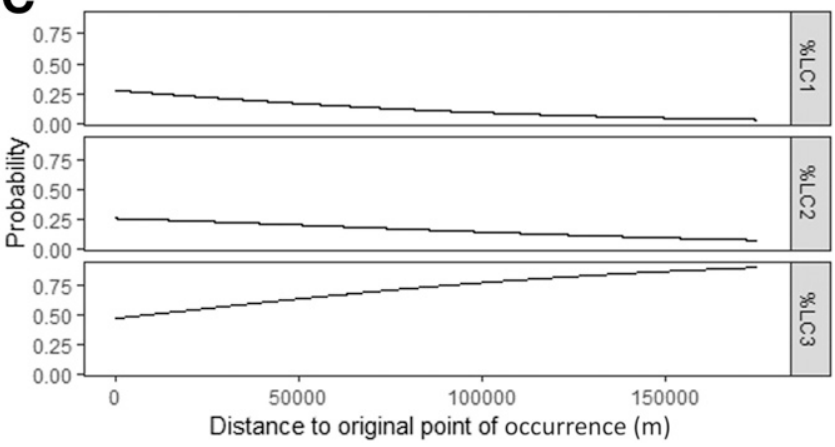

Fig. 4. Effect of distance from point of initial canker occurrence on the probability of A, butternut tree canker incidence, B, butternut tree vigor class, and C, butternut tree percent live canopy (\%LC). Vigor was classified as follows: vigor class 1 (V1), nearly dead (where the tree has no leaves except on epicormic shoots and very high desiccation levels); vigor class 2 (V2), dying (where the majority of leaves are derived from epicormic shoots, and there are high desiccation levels); vigor class 3 (V3), fairly vigorous growth (where the tree has abundant terminal branch growth and multiple leaves on terminal branches, and there is evidence of terminal branch desiccation); and vigor class 4 (V4), vigorous growth (where the tree is clearly thriving with no evidence of branch desiccation). Percent live canopy was defined as follows: \%LC1, <25\%; \%LC2, 25 to $75 \%$; and $\%$ LC3, $>75 \%$. 
populations across watersheds could have slowed $O c-j$ spread. Although spread from Maine is the most probable introduction scenario, other scenarios are possible and could include a host jump from an endophyte, a native pathogen, or an introduction from Japanese walnut, an exotic species that is closely related to butternut (Broders et al. 2012). Genotyping the pathogen strains from New Brunswick trees could potentially help clarify the origin of $O c-j$ in the province.

Although most topographic factors measured did not significantly impact canker incidence, elevation was found to significantly affect canker, where higher elevation predicted higher canker incidence. However, the impact of elevation on canker incidence was mostly explained by the distance to the point of initial occurrence, which is linked to the potential length of exposure to the pathogen. In New Brunswick, trees that are closer to the point of initial occurrence are in the northern extent of the Appalachian Mountain range where higher elevation is found. Other potential weather-related factors (e.g., temperature, precipitation, etc.), which were not evaluated in this study, are known to affect canker incidence and severity (Sambaraju et al. 2018). These factors can certainly have a cumulative impact in promoting the viability and dispersal of $O c-j$ or by limiting the host tree's ability to defend against this efficient fungal pathogen.

Conservation of butternut in New Brunswick. Although canker is present throughout the range and $75 \%$ of individual trees are infected, many butternut trees remain healthy and vigorous and, more importantly, are still producing nuts (M. Williams, personal observation). This has enabled the establishment of a range-wide ex situ collection of cryogenically stored embryogenic axes (root-shoot axis containing some cotyledonary tissue; Beardmore and Vong 1998) from New Brunswick trees that will be useful in providing genetically diverse resources for multiple conservation and restoration strategies, such as tree improvement (e.g., hybridization program with $J$. ailantifolia) and resistance screening. Nuts collected for ex situ conservation came mostly from trees that had the highest vigor rating (VC4), and a greater proportion came from trees that were noncankered compared with all trees in the study (data not shown). Because nut production was not assessed for every tree and for every year, the significance of this result is unknown but is logical because canker significantly impacts tree health (crown dieback), which in turn affects nut production. At this time, cryogenic reserve is the only available long-term storage collection of
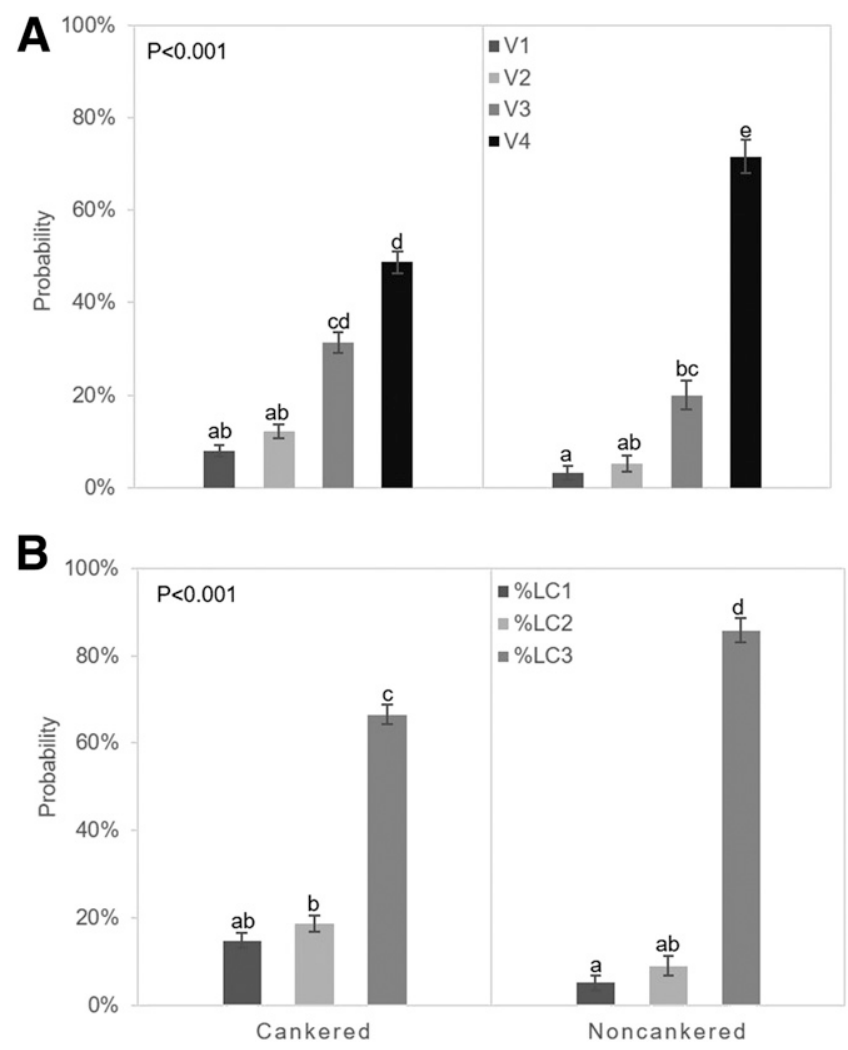

Fig. 5. Effect of canker incidence on the probability of $\mathbf{A}$, tree vigor class and $\mathbf{B}$, tree percent live canopy (\%LC). Vigor was classified as follows: vigor class $1(\mathrm{~V} 1)$, nearly dead (where the tree has no leaves except on epicormic shoots and very high desiccation levels); vigor class 2 (V2), dying (where the majority of leaves are derived from epicormic shoots, and there are high desiccation levels); vigor class 3 (V3), fairly vigorous growth (where the tree has abundant terminal branch growth and multiple leaves on terminal branches, and there is evidence of terminal branch desiccation); and vigor class 4 (V4), vigorous growth (where the tree is clearly thriving with no evidence of branch desiccation). Percent live canopy was defined as follows: \%LC1, <25\%; \%LC2, 25 to $75 \%$; and $\% \mathrm{LC} 3,>75 \%$. Different letter combinations above standard error bars indicate significant pairwise differences in probability.

Table 2. Topographic and physical attributes data from New Brunswick butternut trees

\begin{tabular}{|c|c|c|c|c|c|c|}
\hline \multirow[b]{2}{*}{ Variable } & \multirow[b]{2}{*}{ Sample $(n)$} & \multirow[b]{2}{*}{ Mean \pm SE } & \multirow[b]{2}{*}{ Median } & \multicolumn{2}{|c|}{ Range } & \multirow[b]{2}{*}{$P$ value } \\
\hline & & & & Minimum & Maximum & \\
\hline \multicolumn{7}{|l|}{ Elevation (m) } \\
\hline Total trees & 639 & $41.9 \pm 2.2$ & 12.5 & 2.5 & 255.6 & $0.007^{\mathrm{a}}$ \\
\hline Cankered trees & 477 & $45.3 \pm 2.5$ & & 2.5 & 255.6 & \\
\hline Noncankered trees & 162 & $32.0 \pm 4.5$ & & 2.8 & 246.7 & \\
\hline \multicolumn{7}{|l|}{ Distance to water (m) } \\
\hline Total trees & 639 & $155.4 \pm 7.5$ & 65.0 & 0 & 946 & 0.155 \\
\hline Cankered trees & 477 & $149 \pm 7.9$ & & 0 & 944 & \\
\hline Noncankered trees & 162 & $174 \pm 18.1$ & & 0 & 946 & \\
\hline \multicolumn{7}{|c|}{ Diameter at breast height $(\mathrm{cm})$} \\
\hline Total trees & 633 & $36.0 \pm 0.8$ & 34.1 & 1.5 & 114.8 & 0.939 \\
\hline Cankered trees & 472 & $35.9 \pm 0.8$ & & 3.6 & 112.5 & \\
\hline Noncankered trees & 161 & $36.1 \pm 1.7$ & & 1.5 & 114.8 & \\
\hline \multicolumn{7}{|l|}{ Habitat type } \\
\hline Total trees & 639 & & & & & 0.271 \\
\hline Cankered trees & 477 & & & & & \\
\hline Riparian & 258 & & & & & \\
\hline Upland & 219 & & & & & \\
\hline Noncankered trees & 162 & & & & & \\
\hline Riparian & 96 & & & & & \\
\hline Upland & 66 & & & & & \\
\hline
\end{tabular}

a Statistically significant. 
butternut germplasm. Across New Brunswick, butternut regeneration may have been impacted by decreased mast production attributable to disease pressure, enhanced climate variability, and possibly increased predation of the nuts by small mammals as a result of lower numbers of butternut trees on the sites. Although this was not quantified during the survey, site observations noted that seedlings and saplings are mostly limited to riparian habitats, which exhibit a more disturbed environment (data not shown). The openness of this habitat allows for the germination of this shade-intolerant hardwood species. However, this would only occur if seed predation levels are low enough for seed to be left on the soil surface and for seed to germinate the following year.

Mortality was not quantitatively assessed in this survey. However, an annual mortality rate of $5.43 \%$ was calculated from monitoring 60 sites across the southern Ontario range (Committee on the Status of Endangered Wildlife in Canada 2017). At this rate, a 91\% tree decline is estimated in 45 years (one generation) and a 100\% decline after 84 years (Committee on the Status of Endangered Wildlife in Canada 2017). If the United States and New Brunswick are compared in terms of when canker was first reported (1967 versus 1997), predictions can cautiously be made based on mortality rates in Ontario that, without natural resistance to the canker, New Brunswick stands will be similar to those in the United States and suffer from a high mortality rate, low or no nut production, poor regeneration, and ultimately a dramatic population decline in less than 45 years.

Previous work assessing butternut genotypes has shown that New Brunswick butternuts were genetically unique compared with the rest of the range in the United States (Hoban et al. 2010). Efforts are now ongoing to genotype all of the trees in this study as well as trees across the range in Quebec and Ontario to investigate the genetics of the populations across the range. This information will be instrumental in aiding future conservation efforts, particularly a tree improvement strategy that could include resistance screening of New Brunswick butternuts as well as a hybridization program to breed in tolerance to the pathogen. Unfortunately, this study has shown that timing is critical, as the disease has spread very rapidly through New Brunswick.

\section{Acknowledgments}

This study was made possible because of the help of numerous individuals from many organizations for which we are very grateful. Of the many people who contributed to this effort, we acknowledge, in particular, Dr. Maureen Toner, Eric Sullivan, and Rodney MacEachern (New Brunswick Department of Energy and Resource Development); Chrissy Cusack, Joel Bates, Kyle Parkinson, and Gorica Barudzija (Natural Resources Canada); Aaron Dowding (Nature Trust New Brunswick); Nairn Hay from (Fundy Model Forest); and Fred Bear (Tobique First Nation). In addition, we are very grateful to the many landowners for access to their properties to evaluate their trees. We also acknowledge Dr. Shane Furze for habitat determinations using his digital elevation model and Drs. Maureen Toner and Chris Edge for reviewing this manuscript.

\section{Literature Cited}

Beardmore, T., and Vong, W. 1998. Role of the cotyledonary tissue in improving low and ultralow temperature tolerance of butternut (Juglans cinerea) embryonic axes. Can. J. For. Res. 28:903-910.

Bergdahl, D., and Bergdahl, J. 2009. Assessment of butternut health on public and private lands in the eastern United States. U.S. Department of Agriculture Forest Service poster. https://fhm.fs.fed.us/posters/posters10/asses_butternut_health_ east.pdf

Boraks, A., and Broders, K. D. 2014. Butternut (Juglans cinerea) health, hybridization, and recruitment in northeastern United States. Can. J. For. Res. 44:1244-1252.

Broders, K. D., and Boland, G. J. 2010. Molecular diagnostic assay for detection of the butternut canker pathogen Sirococcus clavigignenti-juglandacearum. Plant Dis. 94:952-958.

Broders, K. D., and Boland, G. J. 2011. Reclassification of the butternut canker fungus, Sirococcus clavigignenti-juglandacearum, into the genus Ophiognomonia. Fungal Biol. 115:70-79.

Broders, K. D., Boraks, A., Sanchez, A. M., and Boland, G. J. 2012. Population structure of the butternut canker fungus, Ophiognomonia clavigignentijuglandacearum, in North American forests. Ecol. Evol. 2:2114-2127.

Committee on the Status of Endangered Wildlife in Canada. 2017. COSEWIC Assessment and Status Report on the Butternut Juglans cinerea in Canada. COSEWIC, Ottawa, ON

Davis, C. N., Myren, D. T., and Czerwinski, E. J. 1992. First report of butternut canker in Ontario. Plant Dis. 76:972.
Fox, J., Weisberg, S., Bates, D., and Fox, M. J. 2012. Package "car". https://cran.rproject.org/web/packages/car/index.html

Furze, S., Ogilvie, J., and Arp, P. A. 2017. Fusing digital elevation models to improve hydrological interpretations. J. Geogr. Inf. Syst. 9:558-575.

Goheen, J. R., and Swihart, R. K. 2003. Food-hording behavior of gray squirrels and North American red squirrels in the central hardwoods region: Implication for forest regeneration. Can. J. Zool. 81:1636-1639.

Golan, J., and Pringle, A. 2017. Long-distance dispersal of fungi. Microbiol. Spectr. 5.

Halik, S., and Bergdahl, D. R. 2002. Potential beetle vectors of Sirococcus clavigignenti-juglandacearum on butternut. Plant Dis. 86:521-527.

Halik, S., and Bergdahl, D. R. 2006. Observations on the natural history, development, range, and future of Eubulus parochus (Herbst) (Coleoptera: Curculionidae). Coleopt. Bull. 60:325-332.

Harrison, K. J., Hurley, J. E., MacKay, A. W., and Sabine, D. L. 2005. Expansion of known distribution of butternut canker (Sirococcus clavigignenti-juglandacearum) in New Brunswick-2004. 2005. Can. Plant Dis. Surv. 85:123-126.

Harrison, K. J., Hurley, J. E., and Ostry, M. E. 1998. First report of butternut canker caused by Sirococcus clavigignenti-juglandacearum in New Brunswick, Canada. Plant Dis. 82:1282.

Hoban, S. M., Borkowski, D. S., Brosi, S. L., McCleary, T. S., Thompson, L. M., McLachlan, J. S., Pereira, M. A., Schlarbaum, S. E., and Romero-Severson, J. 2010. Range-wide distribution of genetic diversity in the North American tree Juglans cinerea: A product of range shifts, not ecological marginality or recent population decline. Mol. Ecol. 19:4876-4891.

Hopkin, A. A., Innes, L., and Harrison, K. J. 2001. Distribution of butternut canker (Sirococcus clavigignenti-juglandacearum) in eastern Canada. Can. Plant Dis. Surv. 81:154-156.

Innes, L., and Rainville, A. 1996. Distribution and detection of Sirococcus clavigignenti-juglandacearum in Quebec. Phytoprotection 77:75-78.

Katovich, S. A., and Ostry, M. E. 1998. Insects associated with butternut and butternut canker in Minnesota and Wisconsin. Great Lakes Entomol. 31: 97-108.

LaBonte, N. R., Ostry, M. E., Ross-Davis, A., and Woeste, K. E. 2015. Estimating heritability of disease resistance and factors that contribute to long-term survival in butternut (Juglans cinerea L.). Tree Genet. Genomes 11:63.

Maine Forest Service. 1994. Forest and Shade Tree Insect and Disease Conditions for Maine: A Summary of the 1993 Situation. Summary Report No. 8, March 1994. Forest Health and Monitoring Division, Maine Forest Service, Maine Department of Conservation, Augusta.

Maine Forest Service. 1995. Forest and Shade Tree Insect and Disease Conditions for Maine: A Summary of the 1994 Situation. Summary Report No. 9, March 1995. Forest Health and Monitoring Division, Maine Forest Service, Maine Department of Conservation, Augusta

Maine Forest Service. 2007. Forest and Shade Tree Insect and Disease Conditions for Maine: A Summary of the 2006 Situation. Summary Report No. 18, March 2007. Forest Health and Monitoring Division, Maine Forest Service, Maine Department of Conservation, Augusta.

Moore, J. E., McEuen, A. B., Swihart, R. K., Contreras, T. A., and Steele, M. A. 2007. Determinants of seed removal distance by scatter-hoarding rodents in deciduous forests. Ecology 88:2529-2540.

Moore, M. J., and Ostry, M. E. 2015. Influence of temperature and humidity on the viability of Ophiognomonia clavigignenti-juglandacearum conidia. Plant Dis. 99:1841-1846.

Morin, R. S., Gottschalk, K. W., Ostry, M. E., and Liebhold, A. M. 2018. Regional patterns of declining butternut (Juglans cinerea L.) suggest site characteristics for restoration. Ecol. Evol. 8:546-559.

Nair, V. M. G., Kostichka, C. J., and Kuntz, J. E. 1979. Sirococcus clavigignentijuglandacearum: An undescribed species causing canker on butternut. Mycologia 71:641-646.

Nielsen, C., Cherry, M., Boysen, B., Hopkin, A., McLaughlin, J., and Beardmore, T. 2003. COSEWIC Status Report on the Butternut Juglans cinerea in Canada. Committee on the Status of Endangered Wildlife in Canada, Ottawa, ON

R Core Team. 2013. R: A Language and Environment for Statistical Computing. R Foundation for Statistical Computing, Vienna, Austria. http://www.R-project.org/

Renlund, D. 1971. Forest Pest Conditions in Wisconsin, Annual Report. Wisconsin Department of Natural Resources, Madison.

Ripley, E. 2016. nnet: Feed-forward neural networks and multinomial log-linear models. https://cran.r-project.org/web/packages/nnet/nnet.pdf

Sambaraju, K. R., DesRochers, P., and Rioux, D. 2018. Factors influencing the regional dynamics of butternut canker. Plant Dis. 102:743-752.

Stewart, J. E., Halik, S., and Bergdahl, D. R. 2004. Viability of Sirococcus clavigignenti-juglandacearum conidia on exoskeletons of three coleopteran species. Plant Dis. 88:1085-1091

Tanguay, P., Blais, M., Potvin, A., Stewart, D., Walker, D., Nadeau-Thibodeau, N., DesRochers, P., and Rioux, D. 2018. qPCR quantification of Ophiognomonia clavigignenti-juglandacearum from infected butternut trees under different release treatments. For. Pathol. 48:e12418.

Tisserat, N., and Kuntz, J. E. 1983. Dispersal gradients of conidia of the butternut canker fungus in a forest during rain. Can. J. For. Res. 13:1139-1144.

U.S. Department of Agriculture Forest Service. 1995. Forest Insect and Disease Conditions in the United States 1994. Forest Pest Management, U.S. Department of Agriculture Forest Service, Washington, DC. 